\title{
Two new Lactarius species, L. flavopalustris and $L$. flavoaspideus, in Fennoscandia
}

\author{
ILKKA KYTÖVUORI
}

KYTÖVUORI, I. 2009: Two new Lactarius species, L. flavopalustris and L. flavoaspideus, in Fennoscandia. - Karstenia 49: 19-31. Helsinki. ISSN 0453-3402.

Two new species with violet staining milk and related to Lactarius aspideus (Fr. : Fr.) Fr. are described from Fennoscandia: L. flavopalustris Kytöv., spec. nova and L. flavoaspideus Kytöv., spec. nova. The distribution of each species is mapped, and their taxonomy, ecology and relationships are discussed.

Key words: Lactarius, Lactarius aspideus, Lactarius flavidus, Fennoscandia, taxonomy

I. Kytövuori, Botanical Museum, P.O. Box 7, University of Helsinki, Finland; e-mail ilkka.kytovuori@helsinki.fi

\section{Introduction}

According to Heilmann-Clausen et al. (1998) Lactarius section Uvidi (Konr.) Bon, subsection Aspideini Singer, consists of seven species in Fennoscandia. One of them: L. flavidus s. Korhonen, also presented in Korhonen (1984), has long been known in Finland, but still it has been without a valid name. During the study an additional species appeared to be present in the group.

\section{Material and methods}

A total of about 310 collections were studied, and 240 were identified to be the species studied here. Most of the author's collections (about 80 specimens) were gathered in Finland, Sweden and Norway during the years 1979-1989 (deposited in H). The collections of Lactarius aspideus, L. flavidus, L. salicis-herbaceae and L. salicisreticulatae held in H, TUR, TUR-A and OULU were also included. The acronyms follow those used by Holmgren et al. (1990).

Macroscopic characteristics were observed from fresh fruitbodies and several collections were used for the descriptions. Some collections were also photographed in fresh condition.

Microscopic characteristics were examined with a light microscope (Leitz Laborlux 12) at magnifications of about $\times 625$ and $\times 1560$. Spores were examined from the surface view of pieces of gills of dried basidiomes and measured with an ocular micrometer. Only mature spores in a perpendicularly lateral position were measured. Young, anomalous, very small or gigantic spores were excluded. Mostly 20 spores per specimen (13-50 in few cases) were measured from one fruitbody (12-16 collections per species). The spore surface ornamentation was excluded in the measurements; length and width were measured from the same spore and the length/width ratios (Q-value) were calculated for individual spores. Cystidia were examined and drawn at the same magnification from the same slides (6 collections per species), and measured with an ocular micrometer and from the drawings.

A few collections (L. flavopalustris Kytövuori 07-142; L. flavoaspideus Kytövuori 90-1641, 2.VIII.1979 Issakainen, Kytövuori 84446; L. flavidus Kytövuori 98-2626; L. aspideus Kytövuori 89-1166, Kytövuori 90-2049) were sequenced to determine the ITS sequence of each species (for method see Kytövuori et al. 2005a, where it was very successful with Cortinarius). However, the procedure was less successful with these Lactarius collections and only a partial ITS sequence of L. flavopalustris Kytövuori 07-142 was obtained.

The vegetation zones of Fennoscandia are given according to Ahti et al. (1968) and the biological provinces according to Knudsen and Vesterholt (2008). For a survey of the geology of Fennoscandia, see Hultén (1971: 38).

The illustrations are those of the author. 


\section{Key to the Fennoscandian species of subsection Aspideini}

1. Milk staining the bruised areas violet 2

- Milk not staining the bruised areas violet Lactarius spp.

2. Cap whitish brownish to greyish to brown Lactarius subsect. Uvidi

- Cap whitish yellowish to yellow 3

3 Cap margin bearded, robust species .... 4

- Cap margin \pm glabrous, fairly robust to small species 5

4 Cap deep yellow, cap margin broadly strongly bearded with long hairs, with Picea or Betula (also B. nana), hemiboreal to oroarctic L. repraesentaneus (not treated)

- Cap whitish yellowish, cap margin narrowly bearded with short hairs, mostly with Dryas, oroarctic

L. dryadophilus (not treated)

5 Mostly with dwarf Salix, mostly in oroarctic habitat

- With Salix, Betula or other deciduous trees, mostly in lowland

6 Cap pale citrine yellow, gills distinctly cream-coloured, spores not reticulate

L. salicis-reticulatae (not treated)

- Cap pale ochraceous yellow, gills more whitish, spores with strong, dark reticulum

L. salicis-herbaceae (not treated)

7 With Corylus, Quercus, Carpinus, Fagus etc., taste acrid, temperate to hemiboreal .....

L. flavidus (not treated)

- With Salix or Betula, taste mild to weakly bitterish, temperate to boreal 8

8 With Betula, mostly fairly robust, cap fairly deep citrine, strongly slimy, spores with coarse broad ridges, not reticulate

L. flavopalustris

- With Salix, smaller, cap paler-coloured, at most thinly slimy, spores reticulate or not

9 Mostly with Salix myrsinifolia, cap pale citrine, thinly slimy, spores with dense, mostly narrow ridges, not reticulate 2. L. flavoaspideus

- Mostly with Salix caprea, cap whitish to straw-coloured, viscid, spores incompletely reticulate 3. L. aspideus

\section{Lactarius flavopalustris Kytöv. spec. nova -} Figs. 1, 4-7

MycoBank no.: MB513252

Lactarius flavidus Boud. in Korhonen (1984) p.p.

Lactarius flavidus s. Korhonen in HeilmannClausen et al. (1998): 95.

Pileus 4.5-13 cm latus, margine (sub)glabro, citrinus, interdum margine ochraceo, crassiter glutinosus; stipes 3-11 cm longus, 1-2(-2.5) cm crassus, cavus, citrinus, crassiter glutinosus; latex albus, areis contusis violaceis. Sapor mitis, lente leviter amarus. Sporae 7.7-9.3(-10.2) $\times$ 6.1-7.3 $\mu \mathrm{m}$, ellipsoideae ad subglobosae, ornamento amyloideo non reticulato. Pleuromacrocystidia aliquot abundantia, 66-93 × 9-14.5 $\mu \mathrm{m}$, anguste fusiformia. Cheilomacrocystidia abundantissima, 35-80 × 6-11 $\mu \mathrm{m}$, anguste fusiformia. In Fennoscandia calciphilus, in silvis uliginosis, cum Betula. Augustio et Septembri.
Holotypus: Finland. Oulun Pohjanmaa (OP/ Obo): Kiiminki, Keskikylä, Pöksälänkangas, S side of the road, opposite to the relay station, mesic spruce forest with some Betula, Populus tremula and Pinus, on calcareous ground, UTM grid: MN2, Grid $27^{\circ} \mathrm{E}$ : 7227:3335, 16 Aug 2007 M. Toivonen \& I. Kytövuori 07-142 (H-6000373, isotype S, Fig. 1). GenBank no.: FJ899595.

Illustrations: Korhonen (1984): 125. Heilmann-Clausen et al. (1998): 95.

Larger and more robust than the other species treated here. Pileus $4.5-13 \mathrm{~cm}$, plano-convex when young, later plano-depressed, pale citrine yellow to bright yellow, evenly coloured or somewhat more ochre and darker at the disc, mostly very weakly zonate with obscure concentric rows of ochre watery spots or zigzag pattern, glabrous at the margin even when young to very weakly, shortly hairy, very slimy. Lamellae fairly crowded, 55-85 reaching the stipe, 1-4 lamellulae between each, slightly decurrent, whitish to pale pinkish buff when young, later pale violet 
buff, straight, seldom forked. Stipe 3-11 cm long, $1-2(-2.5) \mathrm{cm}$ thick, mostly unsymmetrical, often thickest at the middle part and slightly tapering to the base and to the top, yellow (concolorous with the pileus), strongly slimy, evenly coloured or weakly scrobiculate with obscure ochre spots, hollow often with a large cavity when old. Milk abundant, white, not changing colour in itself, but slowly staining the bruised areas violet (not dark), mild, mostly with weakly bitter aftertaste (Fig. 1).

Spores 7.7-9.3(-10.2) $\times 6.1-7.3 \mu \mathrm{m}, \overline{\mathrm{Q}}=$ 1.20-1.44 (333 spores, 17 specimens), $\overline{\mathrm{x}}=$ $8.0-9.2 \times 6.4-6.8, \overline{\mathrm{Q}}=1.25-1.36$, broadly oblong ellipsoid to subglobose, with an amyloid, fairly coarse ornamentation of strong ridges, elongated warts and very small warts up to $1 \mu \mathrm{m}$ high, not forming a reticulum, pale background fairly largely exposed, plage fairly small, mostly inamyloid, weakly amyloid in some spores (Figs. 5 and 6). Pleuromacrocystidia abundant, fusoid, large, 66-93 × 9-14.5 $\mu \mathrm{m}$ (119 cystidia, 6 specimens), with greater part embedded in the hymenium, with the widest point near the top level of the basidioles, projecting up to $40 \mu \mathrm{m}$ above the basidioles, apex mucronate, sometimes moniliform, mostly less acute than in the two following species, contents mostly fairly strongly granulose and/or with globose oil droplets. Pseudocystidia scanty, 3-6 $\mu \mathrm{m}$ thick. Cheilomacrocystidia very abundant, large, but smaller, more slender and more acutely pointed than the pleuromacrocystidia, 35-80 × 6-11 $\mu \mathrm{m}$ (107 cystidia, 6 specimens, Fig. 7). Marginal cells clavate to cylindrical, $10-25 \times 4.5-8.5 \mu \mathrm{m}$. Basidia 4-spored, clavate, 40-55 × 9.5-12 $\mu \mathrm{m}$ (59 basidia, 6 specimens). Pileipellis an ixocutis with a very thick slime layer. Exsiccates: pileus straw yellow to pale yellow ochre, with yellow brown to brown disc, stipe pale yellow ochre, sometimes more brownish at the base, the clear slime layer of the stipitipellis $50-80 \mu \mathrm{m}$ thick.

Ecology and distribution: Lactarius flavopalustris is an exacting species most often growing in eutrophic damp grass-herb mixed forests dominated by Picea abies, along margins of eutrophic spruce-hardwood swamps and with trees and bushes in such swamps. It is not dependent on Salix species. Maybe the main associate is Betula but Salix species are often present, too. It is completely missing from man made habitats. The distribution of Lactarius flavopalustris is typically boreal, even though the southernmost occurrences are known in the hemiboreal zone and one collection is known from above the tree line in the fjeld (Fig. 4). The optimum is distinctly in the middle and northern boreal zones. The species is rare in most of its distribution area. In some eutrophic and limerich areas, e.g. in the Kuusamo, and Tornio Rovaniemi areas in North Finland, and in Jämtland and parts of Lappland in Sweden, it can be locally more common.

Discussion: Usually Lactarius flavopalustris is very easily distinghuished from the other two species treated here, by its larger and brighter yellow basidiomes and different habitat. It can resemble $L$. repraesentaneus and the yellow species of the section Scrobiculati. From the former it differs by the smaller size and glabrous cap margin, from the latter by the mild milk, staining the bruised areas violet contrary to the hot and yellow-turning milk of those. Exsiccates are best distinguished by the abundant, large cheilomacrocystidia - in the Scrobiculati group cheilomacrocystidia are practically absent. Korhonen (1984) reports the spores of L. flavidus s. Korhonen to be distinctly larger, this is because his material is a mixture including L. flavoaspideus.

Lactarius flavidus Boud., too, have large fruitbodies but those are paler in colour, less slimy, have an acrid taste and the staining is very strong. That species grows in temperate to hemiboreal deciduous forests on mull soil and is completely lacking in the boreal zone.

Because no name has been allocated to the present, conspicuous, northern species, the new name, Lactarius flavopalustris, is applied here. The epithet refers to the yellow colour and the most typical habitat of the species.

Specimens examined: NORWAY. Hedmark: Tolga-Os, Os, 2.IX.1986 Kytövuori (H). Sogn og Fjordane: Luster, Fortun, 8.IX.2000 Niskanen \& Kytövuori (H). Møre og Romsdal: Stordal, Storlihornet, 20.VIII.2005 Larsen 63-05 \& al. (TUR-A). Troms: Nordreisa, Javroaive, 2.IX.1954 Stordal 9753 (O). Storfjord, Skibotndalen, 19.VIII.2004 Vauras 21739 (TUR). - SWEDEN. Dalsland: Tisselskog, Råvarpen, 14.IX.1990 Vesterholt (H). Uppland: Gustavsberg, Aug. 1889 Kugelberg (S). Österåker, Hjällmsättra, 13.IX.1984 Kytövuori 84492 (H). Dalarna: Boda, Kärvsåsen, 18.IX.1983 Kytövuori (H); Styggforsen, 22.VIII.1979 Kytövuori 79551 (H). Härjedalen, Storsjö, Ljungdalen, 17.VIII.2006 Toivonen \& Kytövuori 06-147 (H). Ångermanland: Häggdånger, 26.VIII. 1997 Broström (H). Jämtland: Bodsjö, Stuguberget, 4.IX.1997 Kytövuori (H). Frostviken, Gädd- 


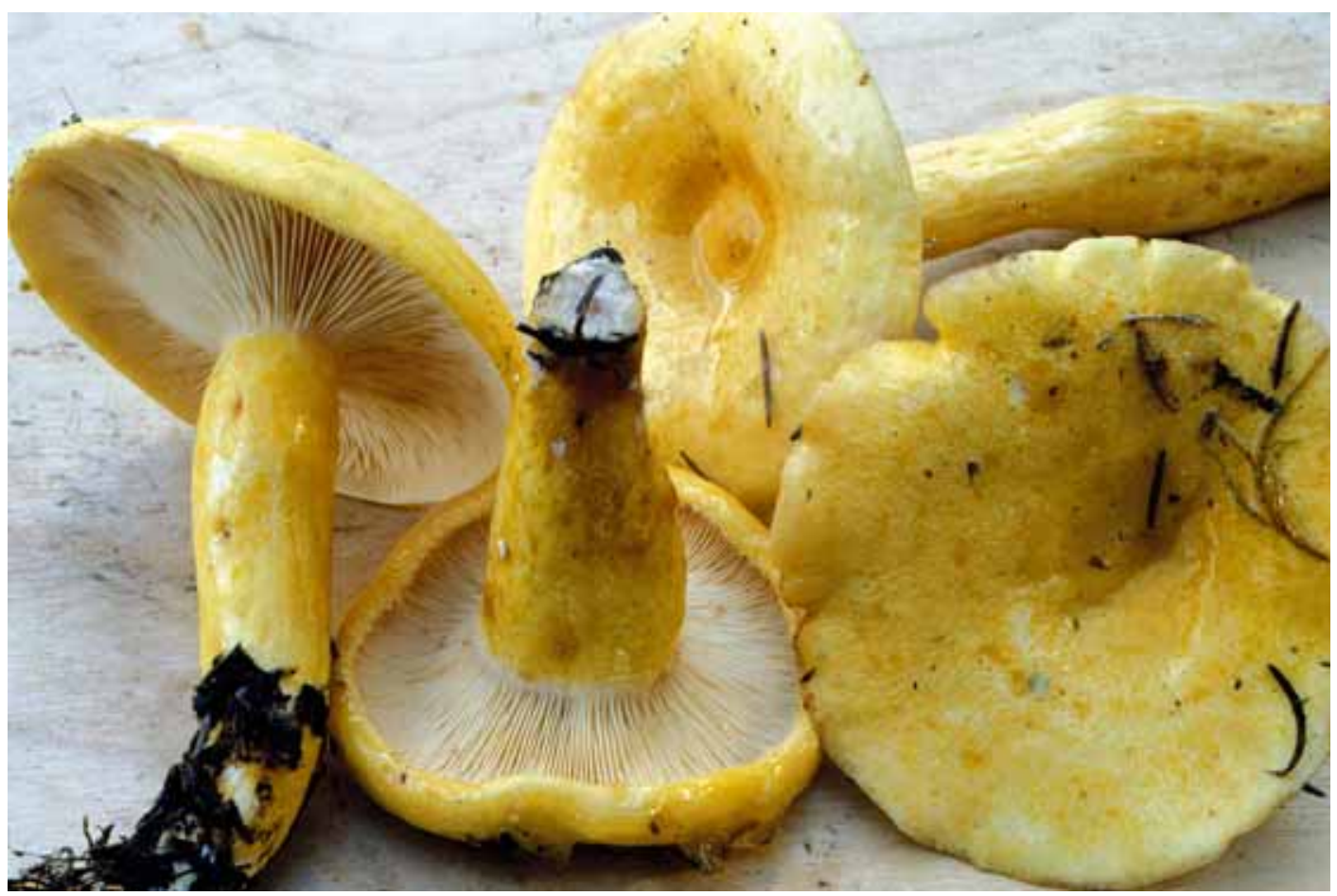

Fig. 1. Lactarius flavopalustris (Finland, Etelä-Pohjanmaa, Laihia, Kytövuori 85650, H). Photo I. Kytövuori.

ede, 18.VIII.1981 Kytövuori 81609 (H); Björkvattnet, 24.VIII.1980 P. \& I. Kytövuori 80467 (H). Undersåker, Getryggen, 21.VIII.2006 Toivonen \& Kytövuori 06385 (H). Åsele Lappmark: Dorotea, Harrsjöhöjden, 9.VIII.1985 Kytövuori 85189 (H). Lycksele Lappmark: Stensele, Umnäs, 21.VIII.1980 P. \& I. Kytövuori 80362 (H). Lule Lappmark: Jokkmokk, Kvikkjokk, 2. 17.VIII.1980 P. \& I. Kytövuori 80249 (H). - FINLAND. Ahvenanmaa: Eckerö, Skag, 17.IX.1978 Ulvinen (OULU). Lemland, Nåtö, 18.VIII.1974 Hoggström (H). Varsinais-Suomi: Karkkila, Haavisto, 7.VIII.2002 Vauras 19062 (TUR). Västanfjärd, Illo, 13.IX.1981 P. \& I. Kytövuori 811382 (H). Uusimaa: Hyvinkää, Kalkkivuori, 8.IX.1979 Kytövuori 79717 (H). Satakunta: Kullaa, Järventausta, 27.VIII.2007 Kosonen (TUR). Etelä-Häme: Heinola, Mataraniemi, 19.VIII.1991 Kytövuori $(\mathrm{H})$, 22.VIII.1993 Kytövuori 93-395 (H). Hämeenkoski, Laaviosuo, 31.VIII.1972 Tuomikoski (H). Lammi, Biological station, 8.IX.1977 Korhonen 2017 (H), 23.VIII.1977 Harmaja $(\mathrm{H}), 25$. VIII.1977 Harmaja $(\mathrm{H})$. Somero, Palikainen, 27.VIII.2000 Heinonen (TUR). Etelä-Pohjanmaa: Laihia, Vanha-Kaija, 2.IX.1985 Kytövuori 85650 (H). Pohjois-Savo: Vehmersalmi, Puutosmäki. 19.IX.1991 Hakala (H). Pohjois-Karjala: Juankoski, Ala-Siikajärvi, 28.VIII.1985 Kytövuori 85486 (H). Kaavi, Niinivaara, 29.VIII.1985 Kytövuori 85521 (H). Nilsiä, Loutteinen, 1997 Ruotsalainen 4070 (H). Keski-Pohjanmaa: Alajärvi, Ukonmäki, 4.IX.1990 Kytövuori 90-1185 (H). Haаpajärvi, Uusimaa, 14.IX.1992 Kytövuori 92-2319 (H). Kainuu: Kajaani, Hatulanmäki, 23.VIII.1970 Harmaja
(H). Paltamo, Mieslahti, 1.IX.1980 Kytövuori 80608 (H); Tololanmäki, 8.IX.1987 Leinonen (OULU), 25.VIII.1988 Kytövuori 88-822 (H); Oikarila, 10.IX.1983 Kytövuori 83300 (H). Sotkamo, Jormaskylä, 9.IX.2001 Ohenoja (OULU); Kontinjoki, 31.VIII.1980 Kytövuori 80570 (H), 30.VIII.1981 Kytövuori 81915 (H), 9.IX.1985 Куtövuori $85985(\mathrm{H}), 25$.VIII.1988 Kytövuori 88-804 (H), 25.VIII.2000 Ohenoja (OULU). Oulun Pohjanmaa: Kiiminki, Isohalmeenmaa, 12.IX.1970 Ohenoja (OULU), 12.IX.1971 Ulvinen (OULU); Hannus, 5.IX.1996 Rahko (OULU), Jolosmäki, 12.IX.1970 Ulvinen (OULU); Jolosjoki, 2.IX.1974 Ulvinen (OULU); Juuvanjärvi, 17.VIII.2007 Toivonen \& Kytövuori 07-203 (H); Juuvankangas, 21.VIII.1990 M. Ohenoja (OULU); Pyssyvaara, 24.VIII.1976 M. Ohenoja (OULU); Pöksälänkangas, 16.VIII.2007 Toivonen \& Kytövuori 07-142 (H). Pudasjärvi, Korpinen, 23.VIII.1984 Ulvinen (OULU); Kouva, 16.VIII.1972 Ulvinen (OULU). Perä-Pohjanmaa: Keminmaa, Tornivaara, 20.VIII.2007 Kytövuori 07-380 (H). Rovaniemi, Taipale, 2.IX.1981 Kytövuori 811007 (H), 7.IX.1988 Kytövuori 88-1480 (H); Jaatila, 15.VIII.1974 Kytövuori 4899 (H), 11.VIII.1999 Vauras 15081 (TURA), $15085 F$ (TUR-A). Tervola, Kirvesmaa, 24.VIII.2007 Kytövuori 07-702 (H); Pahtaoja, 16.IX.1986 Ohenoja \& Vuorinen (OULU); Pukinselkä, 21.VIII.2007 Kytövuori 07-548 (H). Tornio, Kalkkimaa, 1.IX.1981 Kytövuori 81978 (H). Ylitornio, Kaitajärvi, 9.IX.1997 Kytövuori 97-1020 (H), 9.IX.1997 Kytövuori (H). Koillismaa: Kuusamo, Juuma, 31.VIII.2005 Ruotsalainen \& Vauras 23334 (TUR-A), 22.VIII.1997 Ruotsalainen 4422 (H); 


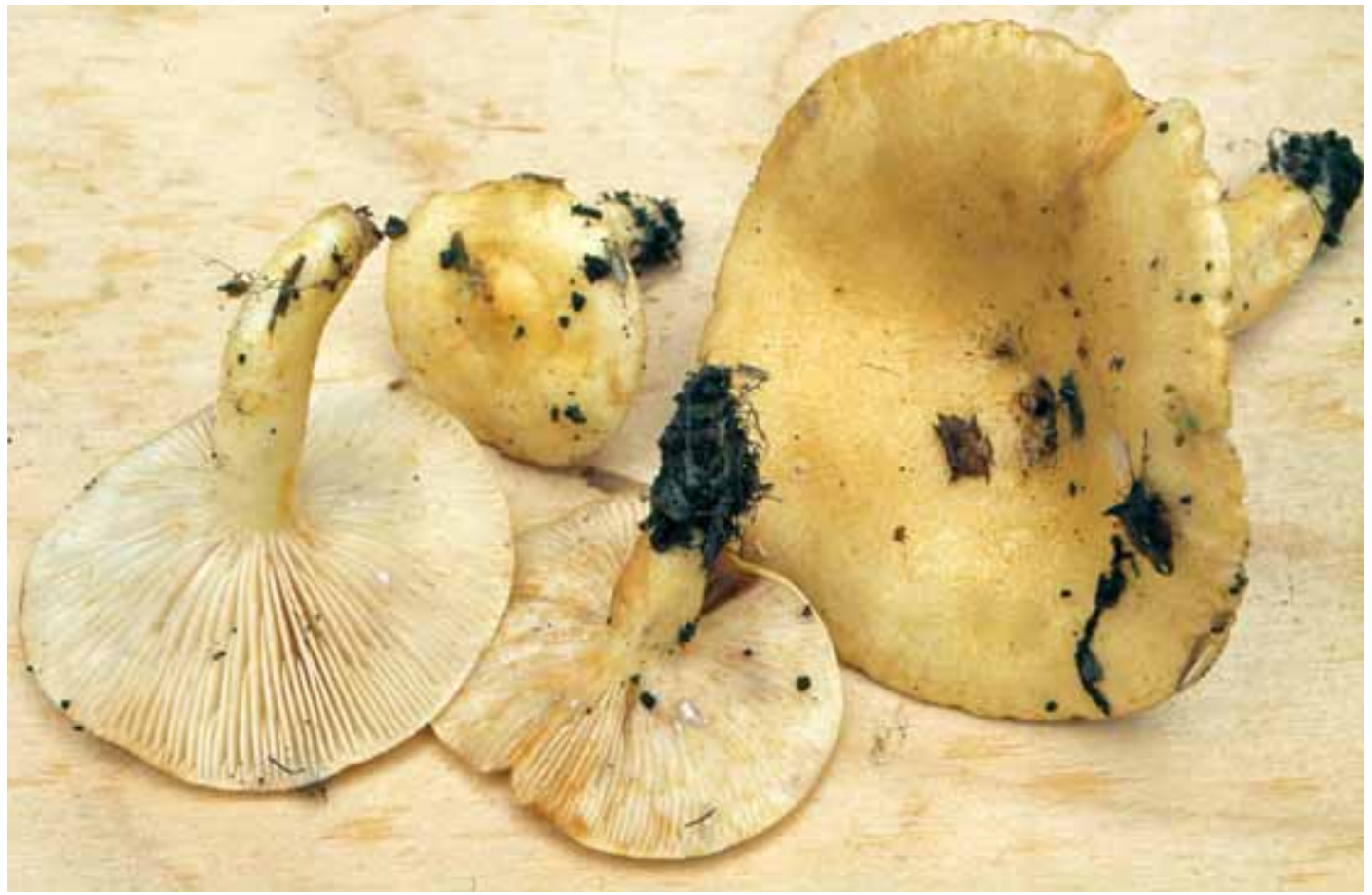

Fig. 2. Lactarius flavoaspideus (holotype, H). Photo I. Kytövuori.

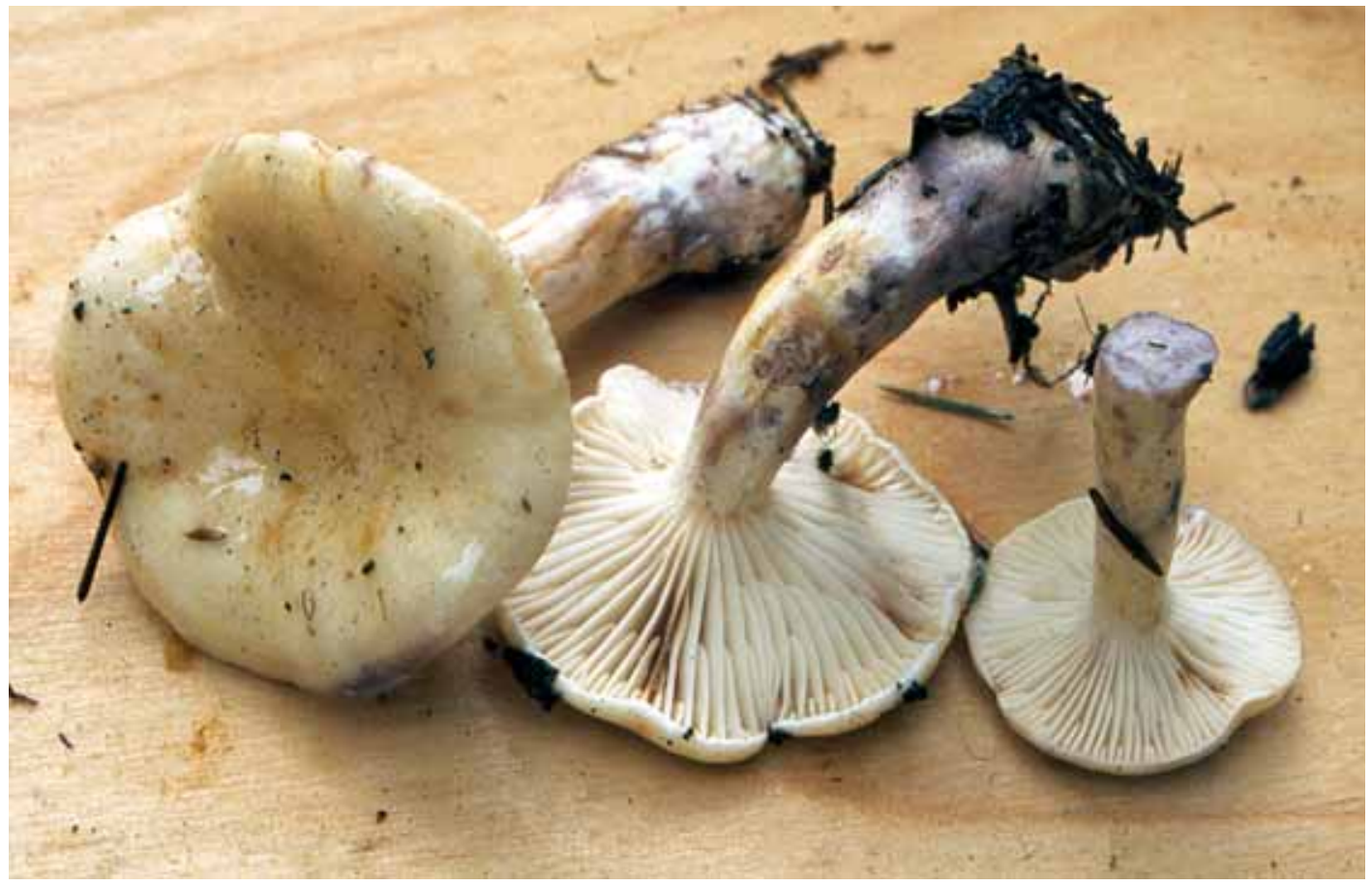

Fig. 3. Lactarius aspideus (Finland, Uusimaa, Kirkkonummi, Kytövuori 84484, H). Photo I. Kytövuori. 


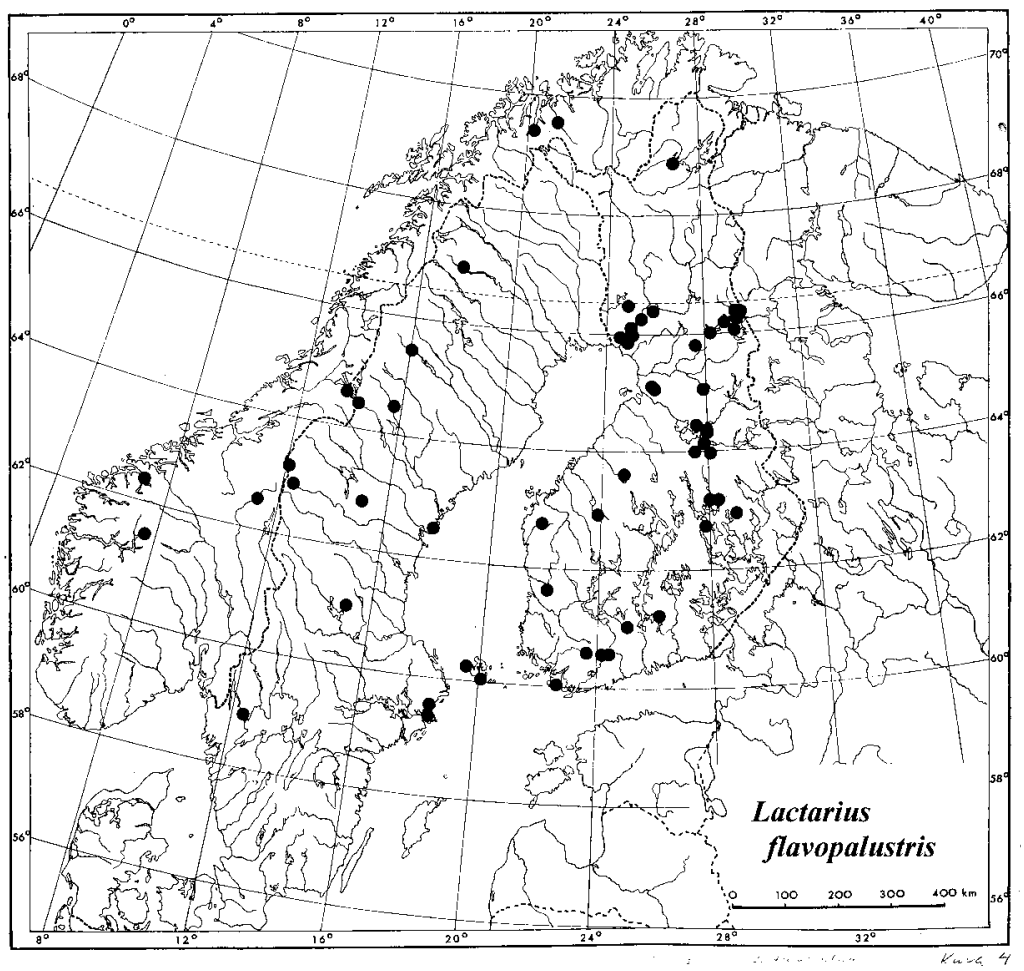

Fig. 4. Distribution of Lactarius flavopalustris in Fennoscandia according to the material examined.
Nissinjärvi, 17.VIII.1973 Kytövuori (H); Kouvervaara, 23.VIII.1997 Ruotsalainen 4433 (H); Hautala, 4.IX.1981 Kytövuori $811168(\mathrm{H})$; Oulanka National Park, Ampumavaara, 24.VIII.1974 Ulvinen (OULU), 22.VIII.1978 Pohjola \& Alanko (OULU), 3.IX.1981 Kytövuori 811104 (H), 11.IX.1981 Ulvinen (OULU), 30.VIII.2007 Campo \& Vauras 25085F (TUR-A); Liikasenvaara, 23.VIII.1971 Harmaja (H), 4.IX.1981 Kytövuori $811152(\mathrm{H})$; Korvasvaara, 25.8.1979 Alanko (OULU), 8.VIII.1978 Issakainen (H), 29.VIII.1981 Korhonen 4098 (H), 10.IX.1981 Ulvinen (OULU), 19.VIII.1983 Seppänen \& al. $65(\mathrm{H})$, 12.VIII.1985 Ruotsalainen \& Vauras 1940F (KUO), 29.VIII.2007 Kytövuori 97-1003 (H). Posio, Livojärvi, 5.VIII.1979 Ulvinen (OULU). Inarin Lappi: Inari, Otsamo, 3.IX.1988 Kytövuori 88-1292 (H).

2. Lactarius flavoaspideus Kytöv. spec. nova Figs. 2, 5-7, 8

MycoBank no.: MB513253.

Pileus 2-5(-7.5) cm latus, margine subglabro, pallide citrinus, margine non fuscato, leviter glutinosus; stipes $1.5-5 \mathrm{~cm}$ longus, $0.4-1.1 \mathrm{~cm}$ crassus, pallide citrinus, leviter glutinosus; latex albus, areis contusis violaceis. Sapor mitis, lente leviter amarus. Sporae 8.4-10.2 × 6.3-7.9 $\mu \mathrm{m}$, late ellipsoideae, ornamento amyloideo non reticulato. Pleuromacrocystidia aliquot abun- dantia, 45-90 × 7.5-11(-12.5) $\mu \mathrm{m}$, anguste fusiformia. Cheilomacrocystidia abundantissima, 30-73 × 7-10 $\mathrm{mm}$, anguste fusiformia. In Fennoscandia infrequens, in dumetis uliginosis, cum apprime Salice myrsinifolia. Augustio et Septembri.

Holotypus: Finland. Etelä-Häme: Luopioinen, Kuohijoki, SW of Kipparinlahti, between the small road to Niittylä and Kytöniitty, a thicket of Alnus incana and Salix myrsinifolia (no S. caprea), on soil. UTM grid: LJ2. Grid $27^{\circ} \mathrm{E}$ : 6801:3381. 9.IX.1984 I. Kytövuori 84446 (H, Fig 2).

Pileus 2-5(-7.5) cm, convex-depressed when young, soon plano-depressed, pale citrine, paler than in L. flavopalustris but distinctly brighter yellow than in L. aspideus, not darker at the disk, very weakly zonate with obscure watery zones, margin very weakly densely hairy when very young, soon glabrous; thinly slimy. Lamellae moderately close, 30-50 reaching the stipe, 2-7 lamellulae between each, adnate to weakly decurrent, white to very pale pinkish buff, straight, mostly not forked. Stipe 1.5-5 cm long, 0.4-1.1 $\mathrm{cm}$ thick, of even thickness or weakly clavate, 
mostly unsymmetrical, pale citrine as the pileus, not spotted, more whitish at the top, thinly slimy. Milk white, not itself changing colour, but slowly staining the bruised areas violet (not dark), mild with a slightly bitterish aftertaste or not (Fig. 2). Spores 8.4-10.2 × 6.3-7.9 $\mu \mathrm{m}, \overline{\mathrm{Q}}=$ $1.21-1.40$ (363 spores, 16 specimens), $\overline{\mathrm{x}}=8.8$ $9.7 \times 6.8-7.4 \mu \mathrm{m}, \overline{\mathrm{Q}}=1.25-1.35$, broadly oblong ellipsoid, fairly strongly ornamented by strongly amyloid, broken, curved, nodulose ridges, elongated to very small warts and very thin line bits, not forming a reticulum (ornamentation denser than in L. flavopalustris), up to $1 \mu \mathrm{m}$ high, plage fairly small, inamyloid or sometimes weakly amyloid (Figs. 5 and 6). Pleuromacrocystidia large, narrowly fusoid, slightly narrower than in L. flavopalustris, 45-90 × 7.5-11(-12.5) $\mu \mathrm{m}(229$ cystidia, 12 specimens), with greater part embedded in the hymenium, with the widest point near the top level of the basidioles, projecting up to 35 $\mu \mathrm{m}$, with contents weakly, obscurely granulose and/or with globose oil droplets. Pseudocystidia 3-6 $\mu \mathrm{m}$ thick, fairly scanty. Cheilomacrocystidia very abundant, large, but somewhat smaller than the pleuromacrocystidia, 30-73(-82) $\times 7-10 \mu \mathrm{m}$ ( 217 cystidia, 12 specimens), very acutely pointed with long, narrow, often moniliform apex (Fig. 7). Marginal cells clavate to cylindrical, 10-25 $\times$ 5-7 $\mu \mathrm{m}$. Basidia 4-spored, clavate, 42-60 × 9-12 $\mu \mathrm{m}$ (52 basidia, 10 specimens). Pileipellis an ixocutis. Exsiccates: pileus yellow ochre, the disc not darker or brown, stipe paler than the pileus or brownish at the base, the clear slime layer of the stipitipellis mostly $20-50 \mu \mathrm{m}$ thick.

Ecology and distribution: The species grows in mixed hardwood thickets associated with different Salix species. Mostly the habitats are somewhat damp and half of the known collections are from alluvial thickets along rivers or lakes. One collection is from the foot of a low hummock under a small Salix phylicifolia in a fairly open, oroboreal valley bottom. Some collections are from southern Salix thickets mixed with Alnus incana and Betula. Except the oroboreal habitat, the dominating Salix species has been $S$. myrsinifolia. Altogether the species seems to grow in more natural habitats than L. aspideus. As to the nutrient conditions L. flavoaspideus seems to be somewhat, but not strongly exacting. The range of Lactarius flavoaspideus reaches from the northern part of the hemiboreal zone to the upper oroboreal zone (Fig. 8). The species seems to be fairly rare at least in the southern part of its range. Maybe it can be commoner in the north and in the upper levels when considered that the fungus collections from there are scanty on the whole.

Discussion: Systematically Lactarius flavoaspideus is situated between the species $L$. aspideus and L. flavopalustris. It resembles the former in the size and external appearance, but differs by its brighter yellowish colour, more slimy fruitbodies, larger and more elongated spores and different spore ornamentation. Differences were best revealed when analysing mixed collections from Lohja in South Finland (H. Harmaja during three years) and Juankoski in Central Finland (Kytövuori during two years). Also the ecology is mostly somewhat different. From L. flavopalustris it differs by its smaller size, mostly paler colour, somewhat larger and differently ornamented spores and different ecology. The basidiomes are smaller than in both the other two.

In the north and in fjeld areas Lactarius flavoaspideus can be confused with the arctic alpine yellow species $L$. salicis-reticulatae and $L$. salicis-herbaceae. Especially the former may be similar with its citrine colour, but the gills are cream and more distant and the spores larger. The latter has more brownish yellow colours and larger, reticulate spores.

In North America the stirps Aspideus is small, only three species are presented by Hesler and A.H. Smith (1979). Two of them are very different from Lactarius flavospideus, but the third, $L$. aspideoides Burlingham, is more like that. However, the gills "pale yellow (about concolorous with the pileus in age)" (Hesler \& Smith 1979) points to a very pale cap colour or very deeply coloured gills, both in distinct contradiction with my material. Also the spores seem to be smaller and fruitbodies larger than in my material (type not seen). Thus a new name, L. flavoaspideus is selected for the species described here. The epithet refers to the yellow colour and similarity to the well-known species L. aspideus.

Specimens examined: NORVAY. Nordland: Rana, NE of Mo i Rana, alluvial Salix myrsinifolia thicket, 13.VIII.1985 Kytövuori 85302 (H). Troms: Lyngen, Furuflaten, mesic-rass-herb Betula, Alnus incana, Salix forest, gently pastured by sheep, 18.VIII.1990 Kytövuori 90-400 (H). Kåfjord, Kåfjorddalen, 18.VIII.1992 Printz (H). Storfjord, Lulleslettan, Alnus incana-dominated 


\section{L. flavopalustris}
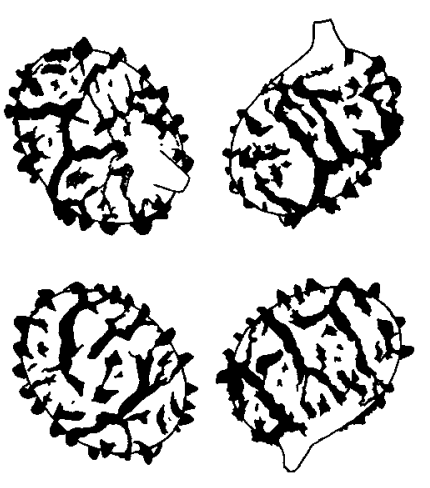

L. flavoaspideus
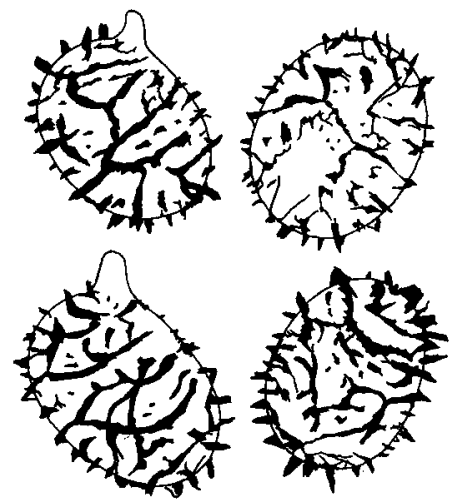

L. aspideus
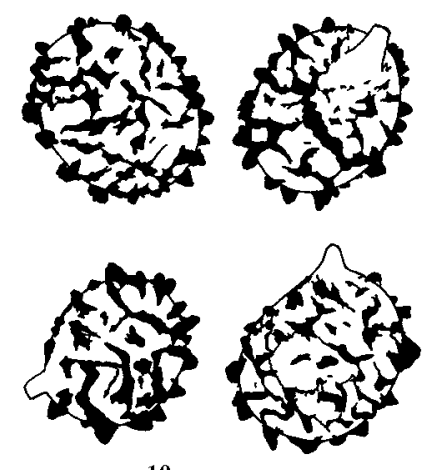

$10 \mu \mathrm{m}$

Fig. 5. Spores of Lactarius flavopalustris (holotype, H), L. flavoaspideus (holotype, H) and L. aspideus (Finland, Uusimaa, Porvoo, Kytövuori 89-1166, H). Scale $\times 2000$.

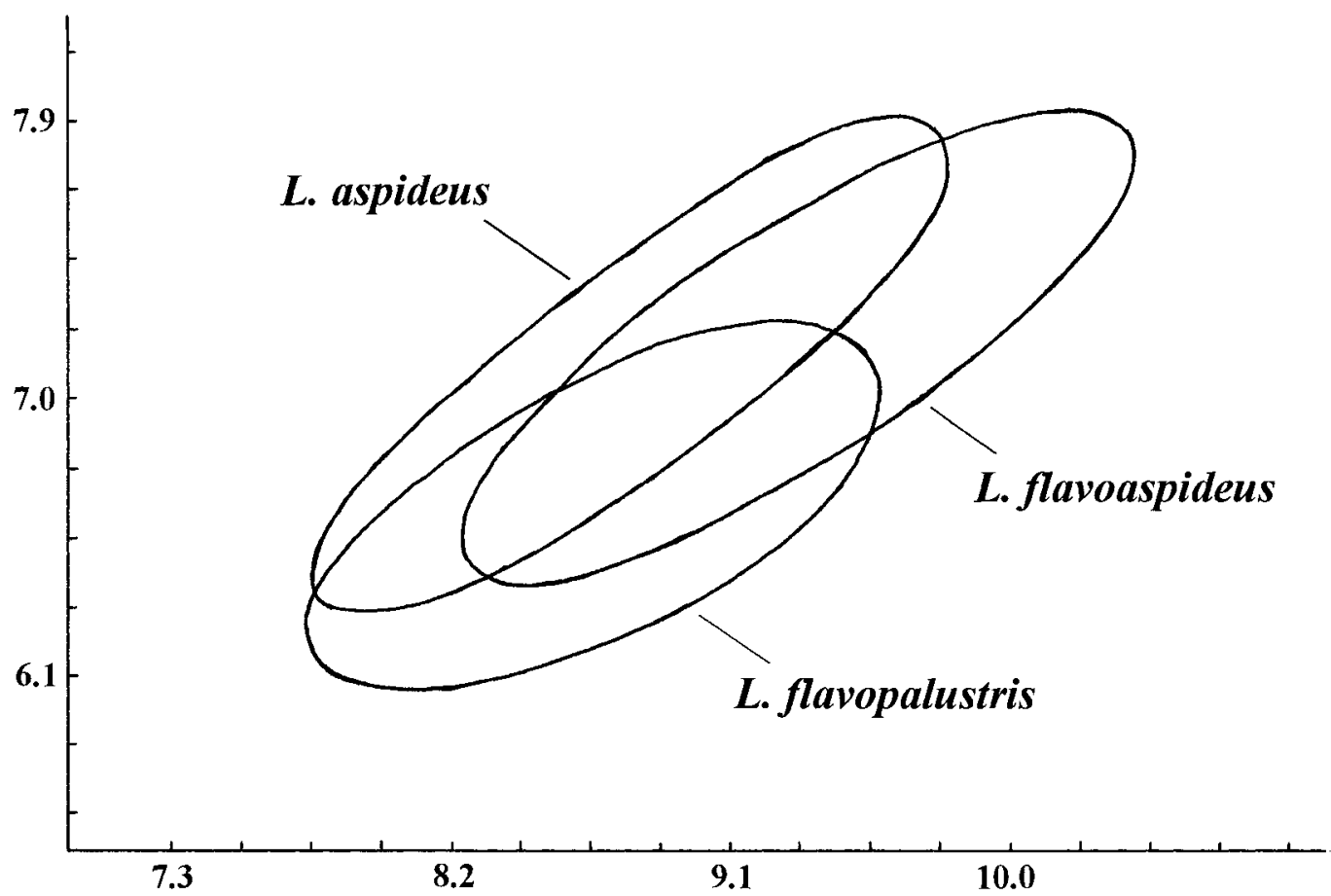

Fig. 6. Diagram showing the spore size of Lactarius flavopalustris, L. flavoaspideus and L. aspideus. The lines are drawn on the basis of scatter diagrams, and represent $95 \%$ of the spores measured for each species. X axis: length of spores. Y axis: width of spores. 


\section{L. flavopalustris}

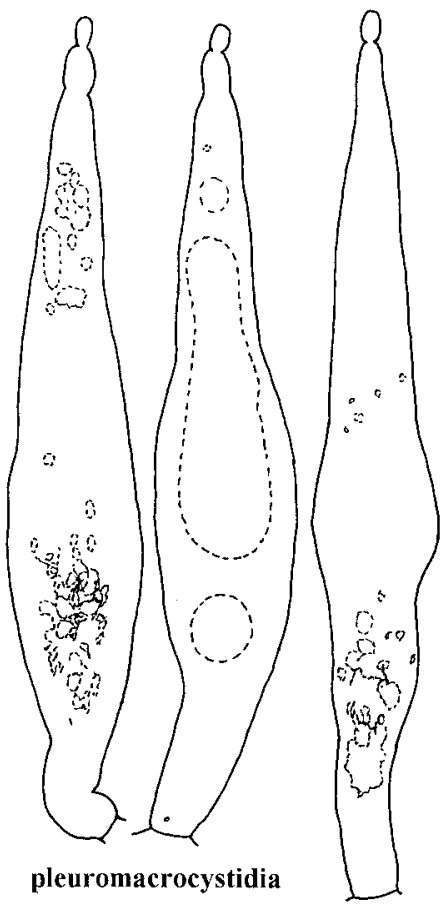

pleuromacrocystidia
L. flavoaspideus

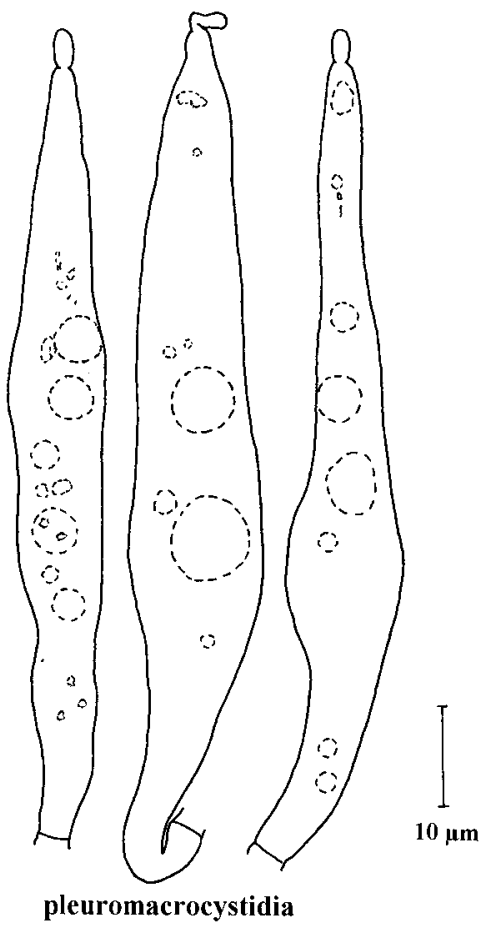

L. aspideus

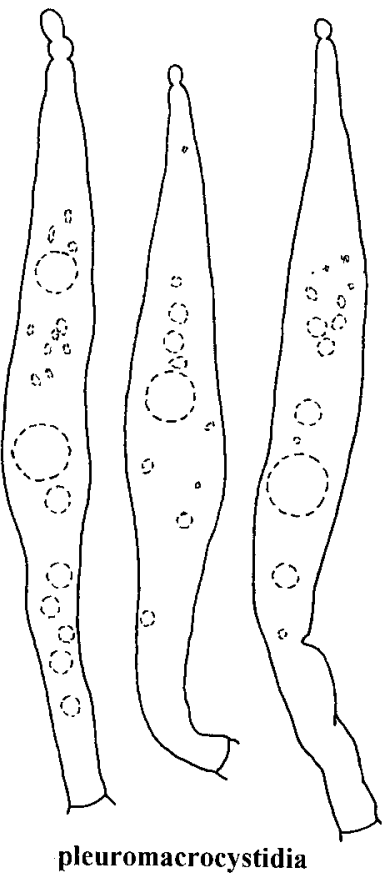

pleuromacrocystidia

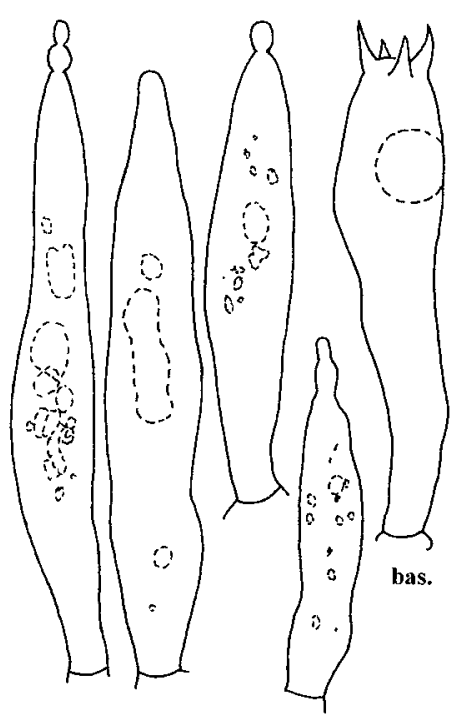

cheilomacrocystidia

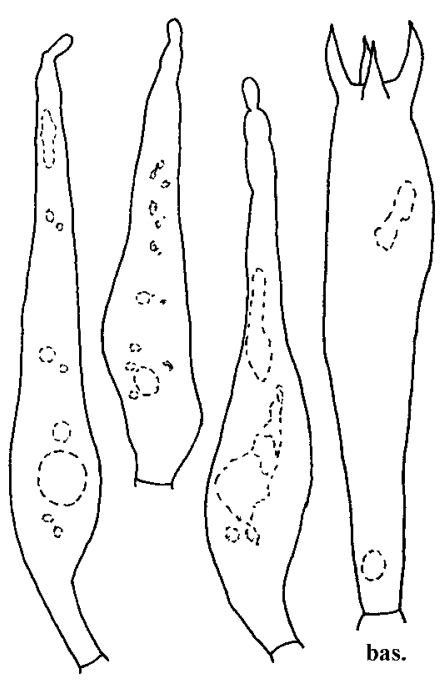

cheilomacrocystidia

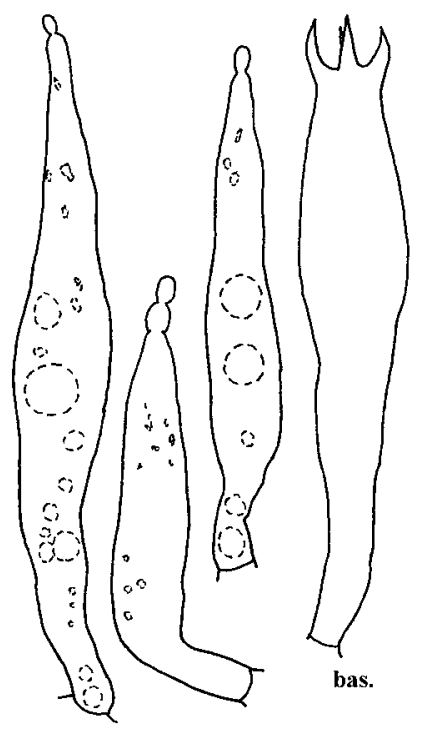

cheilomacrocystidia

Fig. 7. Pleuromacrocystidia, cheilomacrocystidia and basidia of Lactarius flavopalustris (holotype), L. flavoaspideus (holotype) and L. aspideus (Finland, Uusimaa, Porvoo, Kytövuori 89-1166, H). Scale $\times 1000$. 


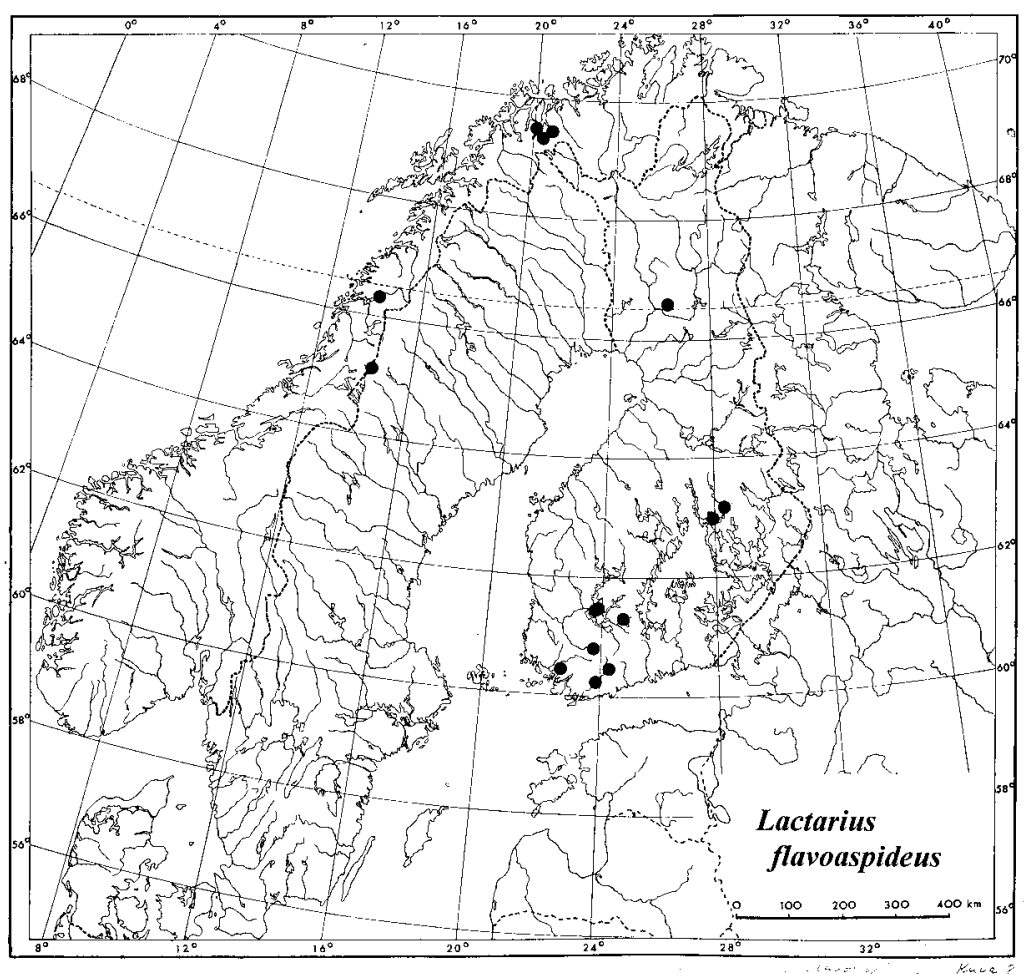

Fig. 8. Distribution of Lactarius flavoaspideus in Fennoscandia according to the material examined. mixed forest, under Salix caprea, 19.VIII.1992 Kaukonen (H, OULU), Sivertsen (H, TRH). - SWEDEN. Åsele Lappmark: Vilhelmina, Stekenjåkk, near the birch line, open, partly paludified Salix thicket, 725 m, 11.VIII.1985 Kytövuori 85218 (H). - FINLAND. Varsinais-Suomi: Karjaa, Lövkullaudden, alluvial lakeside thicket dominated by Salix myrsinifolia and Alnus glutinosa, 25.IX.1990 Kytövuori 90-2037 (H). Lohja, Jalassaari, lakeside thicket, Salix caprea, S. myrsinifolia, 14.IX.1963 Toppari (H), 16.VIII.1965 Harmaja (H), 3.IX.1965 Harmaja $(\mathrm{H})$, 10.IX.1967 Harmaja (H), 5.X.1967 Harmaja (H), 20.VIII.1987 H. \& T. Harmaja (H). Paimio, Juntola, 18.IX.1962 Kukkonen (TUR). Vihti, Katinhäntä, 2.VIII.1979 Issakainen (H). Etelä-Häme: Luopioinen, Kuohijoki, a thicket of Alnus incana and Salix myrsinifolia (no S. caprea), on soil, 9.IX.1984 Kytövuori 84446 (H). Tammela, Mustiala, sub Salice, 8.IX.1874 Karsten (H). Tampere, Messukylä, Salix thicket, 3.IX.1977 Söderholm $277(\mathrm{H})$; Peltolammi, lakeside thicket, Salix, Alnus glutinosa, Betula, 20.VIII.1984 Söderholm 1109 (OULU). Pohjois-Savo: Siilinjärvi, Juurusvesi, 14.VIII.2002 Vauras 19165 (TUR-A). Pohjois-Karjala: Juankoski, AlaSiikajärvi, Salix myrsinifolia thicket with some $S$. caprea, with Lactarius aspideus, 28.VIII.1985 Kytövuori (H), 30.VIII.1987 Kytövuori 87-866 (H). Perä-Pohjanmaa: Rovaniemi, Vikajärvi, 24.VIII.2007 Vauras 24977 (TURA).
3. Lactarius aspideus (Fr. : Fr.) Fr. - Figs. 3, $5-7,9$

Lactarius aspideus (Fr. : Fr.) Fr., Epicr. Syst. Mycol.: 336. 1838. - Agaricus aspideus Fr. : Fr., Syst. Mycol. I: 63. 1821. - Type: not typified.

Illustrations: Korhonen (1984): 124, Ryman \& Holmåsen (1984, 1987): 559, Heilmann-Clausen et al. (1998): 97, Salo et al. (2006): 35.

Pileus 2-8(-10) cm, convex-depressed when young, later plano-depressed, at the margin weakly velutinate when very young, soon glabrous; whitish alutaceous to pale brownish yellowish, mostly evenly coloured, sometimes a bit more brownish at the disc and/or weakly watery zonate at the margin, viscid (to thinly slimy), fairly soon almost dry. Lamellae somewhat distant, 35-46 reaching the stipe, 1-6 lamellulae between each, straight, usually not forked, 3-7 mm high, adnate to weakly decurrent, whitish to pale buff. Stipe 2-7 cm long, 0.6-1.3(-1.8) cm thick, of even thickness to weakly clavate, mostly unsymmetrical, solid to hollow with a 
narrow cavity, pale yellowish buff, evenly coloured or brownish at the base, viscid, soon almost dry. Milk white or very pale yellowish, not itself changing colour, but staining the bruised areas (dark) violet, mild with a slightly bitterish aftertaste or not (Fig. 3). Spores 7.9-9.5 $\times 6.3-$ $7.9 \mu \mathrm{m}, \overline{\mathrm{Q}}=1.17-1.30$ (300 spores, 15 specimens), $\overline{\mathrm{x}}=8.2-9.1 \times 6.6-7.3 \mu \mathrm{m}, \overline{\mathrm{Q}}=1.20-1.25$, (broadly ellipsoid to) subglobose, strongly ornamented by heavily amyloid, nodulose, curved ridges, elongated warts and very thin connections, forming an incomplete reticulum, up to 1 $\mu \mathrm{m}$ high, plage small, inamyloid or sometimes weakly amyloid (Figs. 5 and 6). Pleuromacrocystidia fairly scanty, large, narrowly fusoid, slightly narrower than in L. flavopalustris, 54-90 $\times 8-11(-12) \mu \mathrm{m}$ (90 cystidia, 6 specimens), with the greater part embedded in the hymenium, with the widest point near the top level of the basidioles, projecting up to $35 \mu \mathrm{m}$, with contents clear to very weakly, obscurely granulose and/or with globose oil droplets. Pseudocystidia fairly abundant, 3-5.5 $\mu \mathrm{m}$ thick. Cheilomacrocystidia abundant, large, but somewhat smaller than the pleuromacrocystidia, 33-73 $\times 7-10 \mu \mathrm{m}$ (92 cystidia, 6 specimens), very acutely pointed with long, narrow, often moniliform apex (Fig. 7). Marginal cells clavate to cylindrical, 12-25 $\times$ 4.5-6.5 $\mu \mathrm{m}$. Basidia 4-spored, clavate, 45-63 $\times$ 10-12 $\mu \mathrm{m}$ (79 basidia, 6 specimens). Pileipellis an ixocutis. Exsiccata: pileus alutaceous to pale brownish, sometimes more brown at the disc, yellowish shades mostly disappeared, stipe of the pileus colour or more brown, the clear slime layer of the stipitipellis at most $20 \mu \mathrm{m}$ thick.

Ecology and distribution: Lactarius aspideus is typically a species of man-made hardwood thickets round fields and gardens and along roads and in parks and abandoned house sites, mostly on bare mull soil. The main mycorrhiza partner is Salix caprea, but it can grow with some other Salix species, too, e.g. S. myrsinifolia or S. cinerea. Sometimes it grows among grasses ( $\mathrm{Poa}-$ ceae) and at least two collections are from an uncut hayfield several metres from a Salix caprea bush. It is fairly common in South Finland, but towards the north it is distinctly rarer (Fig. 9). It is also reported from Ahvenanmaa, Etelä-Karjala

Fig. 9. Distribution of Lactarius aspideus in Fennoscandia according to the material examined.

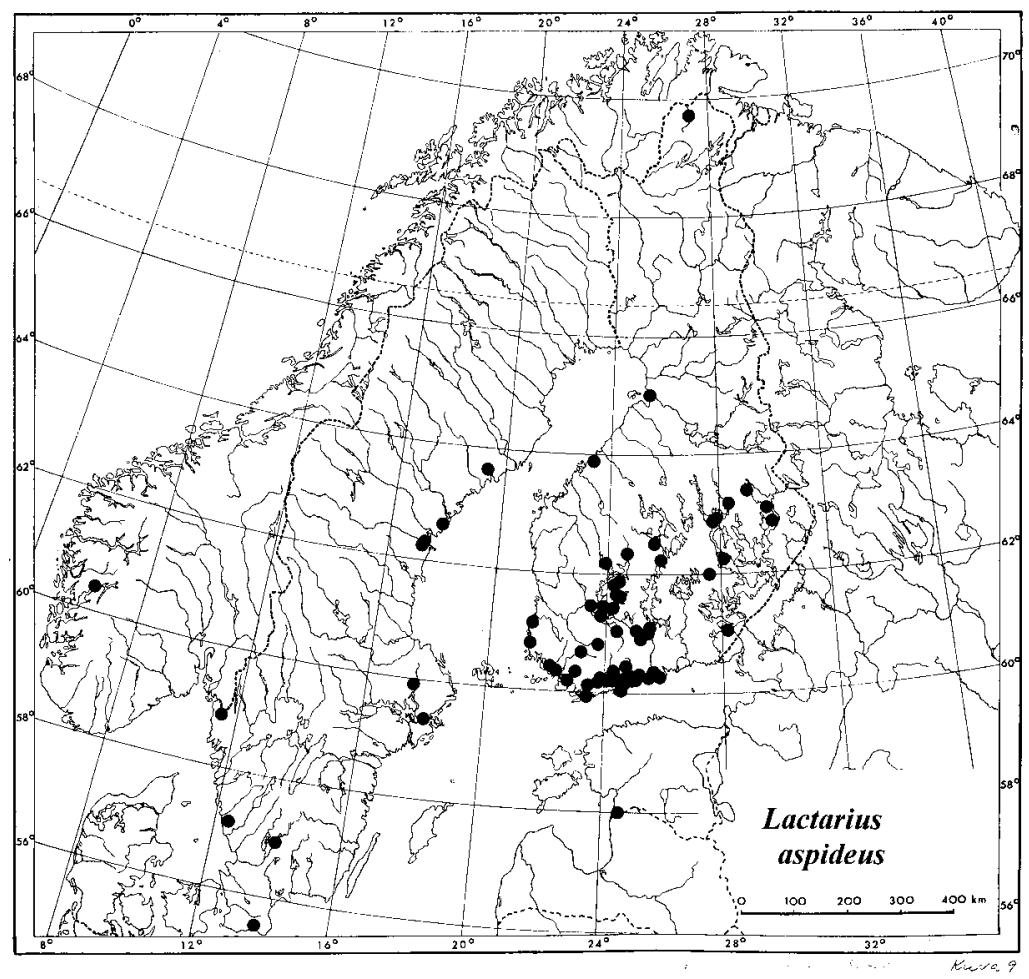


and Koillismaa, in the latter at least five collections, in Kytövuori et al. (2005b), but any correctly determinated $L$. aspideus specimens have not been found. The season of Lactarius aspideus is exceptionally long, in South Finland it reaches from the early June to early November.

Discussion: When the two first species above are separated from Lactarius aspideus, the rest seems to be still somewhat heterogeneous. The size of fruitbodies and the size of spores are very variable. Also the colour of the fruitbody varies from very pale to brownish, especially in dried fruitbodies. I have been compelled to exclude some specimens from the present concept of the species.

Specimens examined: GREAT BRITAIN Scotland: Tays region, Stormont Loch, 12.IX.1991 P. \& I. Kytövuori $(\mathrm{H})$. - NORWAY. Hordaland: Kvam, Ytre Ålvik, 27.VIII.1977 Kytövuori 8153 (H). - SWEDEN. Skåne: Högestad, Lyckås, 20.IX.1984 Kytövuori 84687 (H). Småland: Dörarp, 17.IX.1985 Kytövuori 851165 (H). Halland: Rolfstorp, Stenaljung, 18.IX.1988 Kytövuori 88-1777 (H). Bohuslän: Naverstad, Tingvall, 17.IX.1988 Kytövuori 88-1737 (H). Uppland: Lövö, Drottningholm, 14.IX.1924 Romell (S). Uppsala, Stadskogen, 6.IX.1994 Kytövuori 94-151 (H). Medelpad: Attmar, Sörfors, 5.X.1982 Tedebrand (Muskos 1239). Tuna, Målta, 22.IX.1982 Muskos 1122. Ångermanland: Härnösand, Gerestastigen, 29.VIII.1997 Kyvövuori 97-381 (H). Nordmaling, Djupsjönäs, 28.8.1986 Kytövuori (H). - FINLAND. Varsinais-Suomi: Halikko, Vuorentaka, 11.IX.1988 Kytövuori 88-1621 (H), 10.X.2006 Vauras 24534 (TUR-A). Kaarina, Ala-Lemu, 28.IX.1982 Liponkoski (TUR); Kuusisto, 4.X.1989 Huhtinen 89/80 (TUR), Vauras 4181 (TUR-A). Karjaa, Lövkullaudden, 25.IX.1990 Kytövuori 90-1972 (H), 90-2048 (H), 902049 (H); Mustio, 27.IX.1987 P. \& I. Kytövuori 871731 (H). Kemiö, church village, 10.IX.1966 Siltanen (TUR). Koski Tl, Vähä-Sorvasto, 14.VII.1990 Heinonen 36-90 (TUR), 5.VIII.1992 Vauras 6724F (TUR-A), 29.IX.1996 M.-L. \& P. Heinonen 449-96F (TUR). Lohja, Jalassaari, 14.IX.1963 Toppari (H), 2.IX.1965 Harmaja (H), 3.IX.1965 Harmaja (H), 10.IX.1967 Harmaja (H); Torhola, 29.VIII.1993 Kytövuori 93-592 (H). Parainen, Kirjala, 10.9.2000 M.-L. \& P. Heinonen 449-96F (TUR). Pohja, Pohjankuru, 30.VIII.1990 Kytövuori 90-903 (H). Uusikaupunki, Sundholma, 14.IX.1957 Laine \& Kallio (TUR). Tammisaari, Forstinstitut, 11.IX.1975 Issakainen (TUR). Turku, Ruissalo, 12.IX.1956 Kallio (TUR), Suominen (H). 28.VIII.1957 Kallio (TUR), 3.VIII.1957 Kallio (TUR), 19.IX.1962 Kallio (TUR), 23.IX.1964 Kankainen (TUR), 17.VIII.2000 Vauras 16604F (TUR-A). Vihti, Salmenkartano, 12.X.1989 Kytövuori 89-1484 (H). Uusimaa: Espoo, Kasberg, 22.IX.1948 Tuomikoski (H), 25.IX.1948 Tuomikoski (H); Pirttimäki, 25.VIII.1990 Kytövuori 90-625 (H); Tapiola, Louhentie, 11.X.1963 Toppari $(\mathrm{H})$. Grankulla, 30.IX.1938 Nyberg $(\mathrm{H})$. Helsinki, Annala, 22.VIII.1981 Saarenoksa 41381 (H), 29.IX.1985 Saarenoksa 49985 (H); Kulosaari, 13.7.1981 Saarenok- sa 16181 (H); Kumpula, 2.X.1979 Korhonen 3005 \& Saarenoksa $68179(\mathrm{H})$, 13.VI.1983 Korhonen $5206(\mathrm{H})$; Kumpula-Toukola, 10.VII.1977 Korhonen 1682 \& Saarenoksa $04277(\mathrm{H})$, 12.VIII.1977 Korhonen $1774(\mathrm{H})$, 6.VII.1979 Saarenoksa (OULU), 17.VIII.1981 Korhonen 4034 \& Saarenoksa 40081 (H), 6.VI.1983 Saarenoksa 05983 (H); Maunula, 26.VIII.2000 Kytövuori (H); Myllypuro-Puotinharju, 23.VIII.1977 Saarenoksa 18377 (H); Puotinharju, 5.IX.1985 Saarenoksa (H); Toukola, 8.IX.1992 Saarenoksa 24092 (TUR-A); Vuosaari, 24.VIII.1985 Kytövuori 85411 (H), 31.VIII.1979 Kytövuori $79691(\mathrm{H})$, 11.IX.1966 Ahti (H); Västersundom, 3.IX.1953 Tuomikoski (H); Wiik, 19.IX.1985 Saarenoksa 44885 (H), 20.VIII.1986, Saarenoksa 18486, $40786(\mathrm{H})$, 17.IX.1987 Saarenoksa 29787 (TUR), 17.IX.1989 Saarenoksa 23489 (H). Kirkkonummi, Evitskog, 17.IX.1981 Korhonen 4243 (H), 25.VIII.1979 Saarenoksa 42079 (H); Jorvas, Danskarby, 4.X.1979 Kytövuori 791007 (H), 11.IX.1985 Kytövuori 851017 (H), 5.X.1979 Kytövuori $791012(\mathrm{H})$, 10.IX.1984 Kytövuori 84484 (H); Vols, Kytövuori 90-2351 (H); Väransby, 27.IX.1976 P. Kytövuori \& S.-L. Louhe (H), 26.IX.1993 Kytövuori 93-1522 (H). Nurmijärvi, 11.IX.1978 Askola 707 (H), 26.IX.1979 Askola $830(\mathrm{H})$, 12.IX.1982 Askola $1102(\mathrm{H})$. Porvoo, Bjurböle, 27.VIII.2000 Nummela-Salo \& Salo 7147 (H); Stensböle, 5.VIII.2000 Kytövuori (H); Tirmo, 21.IX.1989 Kytövuori $1166(\mathrm{H}), 18-1324(\mathrm{H})$, Sipoo, Hindsby, 5.X.1975 Saarenoksa 12375 (H), 1.IX.1979 Saarenoksa 47179 (H), 1.VII.1981 Korhonen 3814 \& Saarenoksa 12381 (H), 12.IX.1981 Korhonen 4228 \& Saarenoksa $55081(\mathrm{H})$; Hindsby-Östersundom, 7.IX.1987 Kytövuori 871221 (H); Löparö, 25.IX.1989 Kytövuori 89-1301 (H); Myras-Hindsby, 28.VII.1988 Saarenoksa 04088 (H). Siuntio, Kvarnby, 1.X.1992 Kytövuori 92-2831 (H). Vantaa, Petikko, 17.IX.2000 Nummela-Salo \& Salo $7332(\mathrm{H})$; Silvola, 6.IX.1993 Kytövuori 93-719(H), 93-733 (H); Sotunki, 9.IX.2000 Nummela-Salo \& Salo $7240(\mathrm{H})$. Satakunta: Rauma, Tikkala, 23.IX.1980 Nikkilä (TUR); Hanhinen, 10.IX.1993 Ateva 92 (TUR), 10.X.2004 Ateva 611 (TUR). Etelä-Häme: Hollola, Messilä, 28.IX.1985 Haikonen $6521(\mathrm{H})$; Noitala, 7.IX.1984 Haikonen $4908(\mathrm{H})$. Hämeenlinna, Kankaantausta, 4.IX.1992 Lahti 14/92 (H). Juupajoki, Hyytiålä, 6.IX.2005 J. Korhonen (TUR); Lyly, 19.VII.1984 Kytövuori 84049 (H). Kangasala, Heponiemi, 2.IX.1990 Kytövuori 90-947 (H). Kärkölä, Huovilanpuisto, 11.IX.1985 Haikonen 6330 (H). Lammi, Hauhiala, 10.IX.1986 Mattila (H); Jahkola, 4.IX.1990 Harmaja (H); Pappilankylä, 8.IX.1982 Lampinen (H). Nokia, Haavisto, 18.IX.1976 Jakowlev \& Söderholm (H). Lempäälä, church village, 10.IX.1988 Salo 11485 (OULU). Orivesi, church village, 1974 comm. Siljamäki (H); Päilahti, 26.IX.1995 Kytövuori 95-1558 (H). Tammela, Mustiala, 24.VIII.2000 M.-L. \& P. Heinonen (TUR). Tampere, Kaukajärvi, 6.IX.1975 Söderholm \& Jakowlev (OULU). Etelä-Savo: Juva, Paunola, 21.IX.2004 Vauras 22427 (TUR). Lappeenranta, Hanhijärvi, 15.IX.19898 Kytövuori (H). Pohjois-Häme: Jyväskylä, Nenäinniemi, 30.IX.1997 Saari (JYV). Multia, Tamppikoski, 12.VIII.1991 Kytövuori $(\mathrm{H})$. Uurainen, Jokihaara, 15.VIII.1993 Kytövuori 93-129 (H).Virrat, Hauhuu, 15.IX.1979 Kytövuori 79773 (H), 16.IX.1979 Kytövuori 79772 (H), 5.IX1990 Kytövuori 90-1218 (H). Pohjois-Savo: Juankoski, Ala-Siikajärvi, 28.VIII.1985 Kytövuori 85469 (H), 8.IX.1988 Ky- 
tövuori 88-1506 (H), 28.VIII.1985 Kytövuori $85478(\mathrm{H})$, 30.VIII.1987 Kytövuori 87865 (H). Kangaslampi, Kukkolanmäki, 14.IX.1985 Haikonen 6347 (H). Kuopio, RantaToivala, 31.VIII.1985 Kytövuori 85583 (H); Neulaniemi 31. 11.8.1992 Kytövuori 92-118 (H). Pohjois-Karjala: Eno, Kolvananuuro, 19.IX.1992 Kytövuori 92-2604 (H). Lieksa, Koli, 29.VIII.1956 Tuomikoski (H). Nurmes, Salmi, 19.VIII.2002 Kokkonen \& Vauras 19305 (TUR-A). Keski-Pohjanmaa: Kälviä, Maunumäki, 16.IX.1982 Kytövuori 82439 (H). Oulun Pohjanmaa: Oulu, Hietasaari, 10.IX.1975 Niva \& M. Ohenoja (OULU). Inarin Lappi: Utsjoki, Kevo, 17.VIII.1995 Kytövuori 95-560 (H); Raessijoki, 11.VIII.1962 Kallio (TUR). - ESTONIA. Pärnu: Nigula, 27.VIII.1989 Kytövuori 89-337 (H).

Acknowledgements: I thank Tuula Niskanen, Ph.D., for assistance during the work, Harri Harmaja, Ph.D., for providing me with his specimens and field notes, Kare Liimatainen, MSc., for the sequencening work, Ernest Emmett for help with the English, and Heino Vänskä, Ph.Lic., for revision of the Latin descriptions.

\section{References}

Ahti, T., Hämet-Ahti, L. \& Jalas, J. 1968: Vegetation zones and their sections in northeastern Europe. Ann. Bot. Fennici 5: 169-211.

Heilmann-Clausen, J., Verbeken, A. \& Vesterholt, J. 1998: The genus Lactarius. - Fungi North. Europe: 1-287.
Hesler, L.R. \& Smith, A.H. 1979: North American species of Lactarius. -814 pp. Ann Arbor.

Holmgren, P.K., Holmgren, N.H. \& Barnett, L.C. 1990: Index herbariorum 1. The herbaria of the world. $8^{\text {th }}$ ed. - Regnum Vegetabile 120: 1-693.

Hultén, E. 1971: Atlas över växternas utbredning i Norden, fanerogamer och ormbunksväxter. - 531 pp. Stockholm.

Knudsen, H. \& Vesterholt, J. 2008: Funga nordica. - 965 pp. Copenhagen.

Korhonen, M. 1984: Suomen rouskut. - 223 pp. Keuruu. Kytövuori, I., Niskanen, T., Liimatainen, K. \& Lindström, H. 2005a: Cortinarius sordidemaculatus and two new related species, C. anisatus and $\mathrm{C}$. neofurvolaesus, in Fennoscandia (Basidiomycota, Agaricales). - Karstenia 45: 33-49.

Kytövuori, I., Nummela-Salo, U., Salo, P. \& Vauras, J. 2005b: Helttasienten ja tattien levinneisyystaulukko. Distribution table of agarics and boletes of Finland. - In: Salo, P., Niemelä, T., Nummela-Salo, U. \& Ohenoja, E. (eds.): Suomen helttasienten ja tattien ekologia, levinneisyys ja uhanalaisuus. Suomen ympäristö 769: 109-224.

Ryman, S. \& Holmåsen, I. 1984: Svampar. En fälthandbok. (1987: Pohjolan sienet). - 718 pp. Stockholm.

Salo, P., Niemelä, T. \& Salo, U. 2006: Suomen sieniopas. - 512 pp. Helsinki. 